\title{
非外傷性後骨間神経麻㾝に対する超音波検査の意義
}

\author{
中道健一*1 井田雅祥*1 大賀 辰秀*1 山徳雅人*1
}

\section{Clinical Significance of Ultrasonography for the Diagnosis of Nontraumatic Posterior Interosseous Nerve Palsy}

\author{
Kenichi NaKamichi, ${ }^{* 1}$ Masayoshi IDA, ${ }^{* 1}$ Tatsuhide OGA, ${ }^{* 1}$ Masato YAmatoKu ${ }^{* 1}$
}

\begin{abstract}
Objective : Causes of nontraumatic posterior interosseous nerve (PIN) palsy include space-occupying lesions, constrictions of the PIN, and supinator syndrome. The purpose of this study was to identify these causes using Ultrasonography (US). Methods : We performed US in seven cases (seven elbows) with palsy and examined the PIN and surrounding structures. Results : We identified the three causes by the following US findings : 1) A space-occupying lesion in two elbows. Both were low-echoic and diagnosed as ganglion. In these two cases, the PIN was elevated by the lesion and compressed against the arcade of Frohse. 2) A diffusely swollen PIN with constrictions was found in three cases. 3) A PIN showing a reduction in caliber beneath and a swelling (pseudoneuroma) proximal to the arcade of Frohse, compatible with supinator syndrome was also identified. Conclusion : US is useful for the diagnosis of nontraumatic PIN palsy. (Jpn J Rehabil Med 2013; $50: 328-333$ )

要 旨 目的：後骨間神経（PIN）の非外傷性麻痷の原因には，占拠性病変（主にガングリ オン)，PINのくびれ，絞扼（回外筋症候群）がある．今回，原因の同定に超音波検査（US） を行い有用性を評価した。方法：本麻瘏の 7 例 7 时を対象とした.PIN と周囲組織をUSによ り観察した。結果：以下のUS 所見により 3 原因を同定できた。1）占拠性病変（2 时）：いず れも低エコーでガングリオンと診断した．PIN はこれにより挙上され, Frohse 腱弓で圧迫さ れていた。 2) PIN のくびれと全長性の腫大 (3 肘). 3) Frohse 腱弓下での PIN 径の減少と近 位の腫大（仮性神経腫）（2 肘）：回外筋症候群と診断した。結論：US は非外傷性 PIN 麻痺の 原因検索に有用である。
\end{abstract}

Key words : 非外傷性後骨間神経麻瘏（nontraumatic posterior interosseous nerve palsy), 超 音波検查 (ultrasonography), 占拠性病変 (space-occupying lesion), 神経のくび れ (nerve constriction), 回外筋症候群 (supinator syndrome)

はじめに

後骨間神経（以下 PIN）の非外傷性麻疩の原因に は，占拠性病変（主にガングリオン），PIN のくびれ， 絞扼（回外筋症候群）がある ${ }^{1}$. これらの同定には画 像診断法として超音波検査（以下 US）と磁気共鳴画 像（MRI）が用いられているが，3 原因を鑑別した報 告はない. 本研究の目的は, この点に関するUS の有 用性を検討することである。

\section{対象と方法}

2005 年以降に当科を受診し，US を受けた非外傷性 PIN 麻痖 7 例（男性 6 名，女性 1 名, $24 \sim 74$ 歳） 7 时を対象とした．臨床診断は，橈側手根伸筋を除く前 腕伸筋の麻瘦による手指伸展障害 (下垂指), 手関節 背屈は可能であるが, 橈屈すること, 感覚障害を欠く ことにより行った。電気生理学的検査として針筋電図 を行った．筋萎縮があっても刺入可能な PIN 支配筋

2012 年 12 月 10 日受付, 2013 年 4 月 1 日受理

*1 虎の門病院リハビリテーション科/ $\overline{1} 105-8470$ 東京都港区虎ノ門 2-2-2

Department of Rehabilitation Medicine, Toranomon Hospital

E-mail : torakajinaka@hotmail.com 
として総指伸筋，尺側手根伸筋を対象とし，これらに 神経原性変化があること，腕橈骨筋，長橈側手根伸筋 は正常であることを確認した，使用したUS装置はア ロカ社製 SSD-5000（探触子周波数：7.5 MHz） あるい は東芝社製 Aprio XG（同：18 MHz）であった.PIN の観察法を以下に示す：(1) US 横断像を用いて上腕遠 位外側で橈骨神経本幹を同定，(2)これを遠位に追跡 し，肘窩近位で分岐し橈骨頭から頚部前方を外側に斜 走し回外筋に入るPIN を同定，(3)遠位は前腕近位背 側の回外筋出口部まで追跡，(4)異常所見を認めた部位 でPIN 長軸像の観察。さらにPIN の周囲組織も観察 した。圧迫あるいは腫大部位では，US 付属計測ソフ トを用いて $0.1 \mathrm{~mm}$ 毎に径を測定した。手術例では US 像を術中所見と対比した。

\section{結果}

症例の内訳を表に示す. US では以下の 3 所見を得 た。

1）占拠性病変 $(2$ 肘：症例 1,2$)$ ：いずれも低エコー で，ガングリオンと診断した.PIN のガングリオンに よる挙上, Frohse 腱弓での圧迫（扁平化（症例 $1: 2.6 \times$ $0.8 \mathrm{~mm}$, 症例 $2: 2.3 \times 1.0 \mathrm{~mm}$ (いずれも長径 $\times$ 短径,
以下同))，折れ曲がり像）を認めた。腫瘤は症例 1 で は触知できなかったが，症例 2 では肘窩に触知でき た．前者ではUS下に穿刺を行ったが，麻痺の回復な く再発したため，手術（ガングリオン切除）を行い治 癒した（図 1)．後者は抗血小板製剂投与中であるこ とと内科的合併症のため穿刺，手術を希望せず，経過 観察中である。

2) PIN のくびれと腫大（3 肘：症例 3，4，5）：腫 大は全長性で, PIN の直径は, 症例 $3: 2.5 \mathrm{~mm}$, 症例 $4: 2.4 \mathrm{~mm}$, 症例 $5: 3.0 \mathrm{~mm}$ であった. いずれも肘の 痛みに続いて麻痺を生じた。痛みは 1 肘（症例 5) で

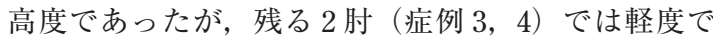

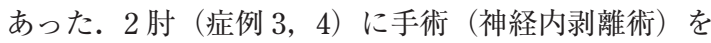
行い，両者とも治癒した（図 2). 症例 5 は経過観察 中である.

3）PIN の Frohse 腱弓下での圧迫，扁平化と同腱弓 近位での腫大 $(2$ 肘：症例 6,7$): P I N$ の径は, 圧迫 部位で症例 $6: 2.7 \times 0.7 \mathrm{~mm}$, 症例 $7: 2.9 \times 1.0 \mathrm{~mm}$, 腫大（仮性神経腫）部位では症例 $6: 4.0 \times 1.7 \mathrm{~mm}$, 症例 $7: 3.2 \times 1.7 \mathrm{~mm}$ であった。いずれも PIN の絞扼 (回外筋症候群) と診断した. 1 时（症例 6）では，事 務所移転時の荷物運搬作業を契機に肘の鈍痛とともに

\begin{tabular}{|c|c|c|c|c|c|c|c|}
\hline 番号 & 年齢 & 性 & 罹患側 & 原因 & $\begin{array}{c}\text { 発症様式 } \\
\text { (麻痺の程度) }\end{array}$ & 治療 & 転帰 \\
\hline 1 & 62 & 男 & 右 & $\begin{array}{l}\text { ガングリオン } \\
\text { (触知不可) }\end{array}$ & $\begin{array}{l}\text { 緩徐発症 (3 カ月) } \\
(\text { 完全麻痺 }) *\end{array}$ & 手術**** & 完全回復 \\
\hline 2 & 74 & 男 & 右 & $\begin{array}{l}\text { ガングリオン } \\
\text { (触知可) }\end{array}$ & $\begin{array}{l}\text { 緩徐発症（6 力月） } \\
\text { (不全麻痺)** }\end{array}$ & 経過観察 & 不変 \\
\hline 3 & 24 & 男 & 左 & くびれ & $\begin{array}{l}\text { 时痛 (軽度) 後急性発症 } \\
\text { (完全麻痺) }{ }^{*}\end{array}$ & 手術**** & 完全回復 \\
\hline 4 & 32 & 男 & 右 & くびれ & $\begin{array}{l}\text { 时痛 (軽度) 後急性発症 } \\
\text { (完全麻痺) }\end{array}$ & 手術**** & 完全回復 \\
\hline 5 & 44 & 女 & 右 & くびれ & $\begin{array}{l}\text { 肘疼痛後急性発症 } \\
(\text { 完全麻痺 })^{*}\end{array}$ & 経過観察 & 不変 \\
\hline 6 & 42 & 男 & 右 & 絞扼 & $\begin{array}{l}\text { 運搬作業後発症 } \\
(\text { 完全麻痺 })^{*}\end{array}$ & $\begin{array}{l}\text { 保存的治療 } \\
\text { (シーネ) }\end{array}$ & 完全回復 \\
\hline 7 & 60 & 男 & 右 & 絞扼 & $\begin{array}{l}\text { 緩徐発症（誘因なし，3 カ月） } \\
\text { (不全麻疾) }{ }^{* * *}\end{array}$ & $\begin{array}{l}\text { 保存的治療 } \\
\text { (シーネ) }\end{array}$ & $\begin{array}{l}\text { 部分回復 } \\
\text { (経過観察中) }\end{array}$ \\
\hline
\end{tabular}

${ }^{*} \mathrm{PIN}$ 支配筋 [0]，EMG：EDC，ECUで MUP なし，PSW，Fib あり。

${ }^{* *}$ EPL [2]，EDC，ECU [3]，EMG：EDC，ECUで多相性 MUP（干渉減弱）あり，PSW，Fib は針 電極刺入後数秒あり.

*** PIN 支配筋 $[0$ あるいは 1 の判定困難 $]$, EMG：EDC，ECUで single oscillation，PSW，Fib あり。

****手術内容：ガングリオン切除（症例 1 ), 神経内剥離術（症例 3,4$)$

(EPL : 長母指伸筋, EDC : 総指伸筋, ECU : 尺側手根伸筋, EMG : 針筋電図, MUP : 運動単位電位, PSW：陽性鋭波，Fib：線維自発電位，[ ] : 徒手筋力検査による筋力） 

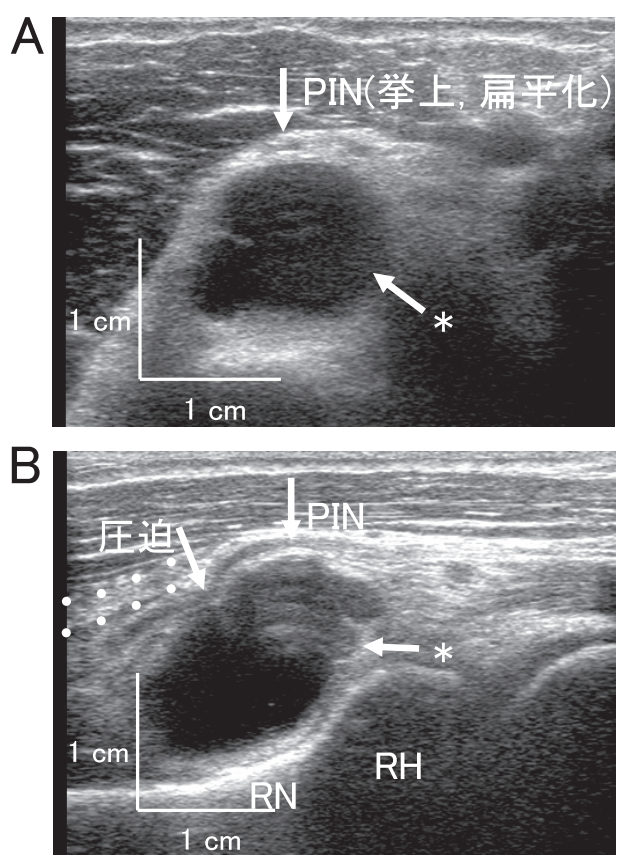
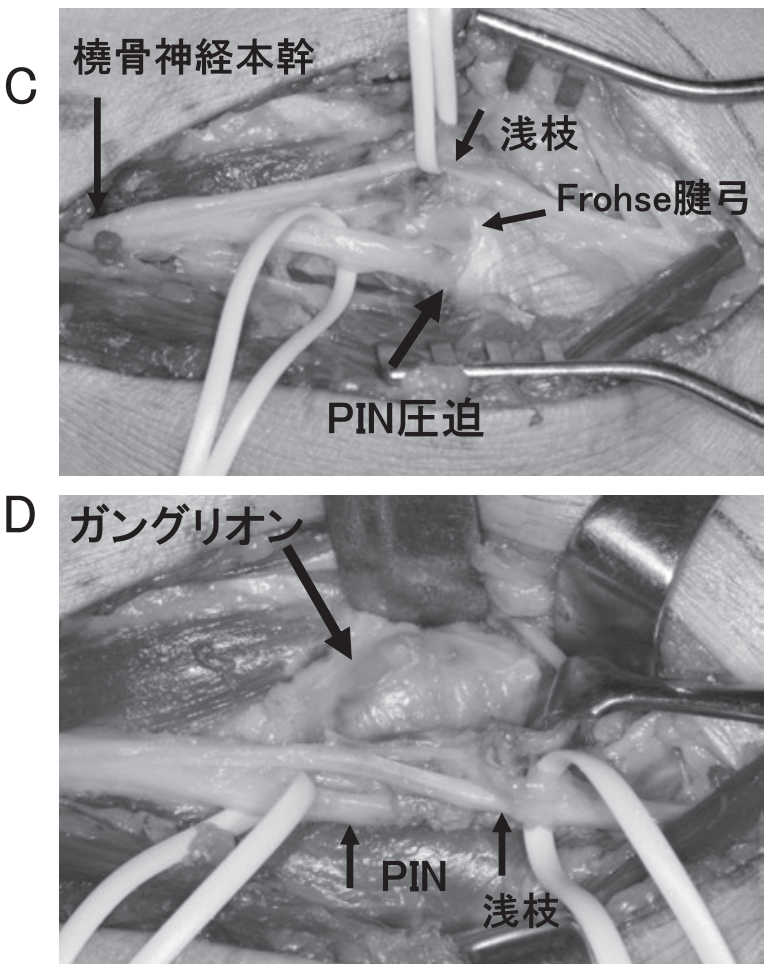

図 1 ガングリオン (表：症例 1)

（A）橈骨頚部高位の US 横断像（左：外側，上：前方)。中央に低エコーの占拠性病変（*) があり，PIN はその前方 に挙上され，扁平化していた（B）同部位の US 長軸像（左：遠位，上：前方）。橈骨頭（RH）から頚部（RN）前方 に低エコーの占拠性病変を認めた（*)．PIN は，これにより前方に挙上され，Frohse 腱弓（ドット）の近位端で圧迫 され，折れ曲がり像を呈していた（C，D）術中写真 (左：近位，上：内側). PINはFrohse腱弓で圧迫されていた (C). 腱弓を切離し，PIN と橈骨神経浅枝を外側によけるとガングリオンを認めた（D).

緩徐進行性に麻痺が出現した（図 3)。本例は，保存 的治療（肘上-手関節固定シーネ（肘関節屈曲 90 度, 手関節中間位）を日中可及的および夜間に 3 力月間装 用）により治癒した。残る 1 肘（症例 7）には誘因は なく, 保存的治療 (同様の固定シーネ) で回復傾向に あるため経過観察中である.上記の PIN の直径, 長, 短径については，全症例で正常值 $(1.3 \pm 0.2 \mathrm{~mm})^{2)}$ の 平均 \pm 2 標準偏差の範囲を超える数值を認め, 異常と 判定した.

\section{考察}

非外傷性 PIN 麻舫の原因同定は治療法を決定する ため重要である．PIN の圧迫をきたす占拠性病変はガ ングリオンが最も多い(1) が，脂肪腫 ${ }^{3)}$, 軟骨腫 ${ }^{4)}$, 滑 膜血管腫 ${ }^{5)}$, 粘液腫 ${ }^{6}$, 滑膜性骨軟骨腫症 ${ }^{7)}$, 滑膜囊 腫 ${ }^{8)}$ の報告があり，いずれも切除手術を要する. ガ
ングリオンはUS ガイド下の穿刺, 除圧も可能である が, 自験例（症例 1）では無効であったため, 手術を 行った.くびれはPINの神経痛性筋萎縮症に特徵的 で, 従来は経過観察が行われたが, 近年は神経内剥離 術の良好な成績が報告され(9), $3 \sim 6$ 力月の待機で改 善しない場合は手術（神経内剥離術）が推奨される傾 向にある。これに対し, 回外筋症候群はFrohse 腱弓 部での絞扼性神経障害で, 安静, 固定を含む保存的治 療が優先される ${ }^{1}$.

原因の推定は臨床的にも可能とされてきた。すなわ ち典型例の特徵は, 占拠性病変では肘窩（橈骨頭から 頚部前方）の腫瘤の触知, PIN のくびれでは肘疼痛後 の急性麻痺, 回外筋症候群では肘関節過用（特に前腕 回内, 外動作）後の進行性麻疩である ${ }^{1)}$. しかし, こ れらは確定診断ではなく，特に非典型例，例えば自験 例にみられた腫瘤が触知できないガングリオン（症例 
後骨間神経麻痺の超音波検査

A

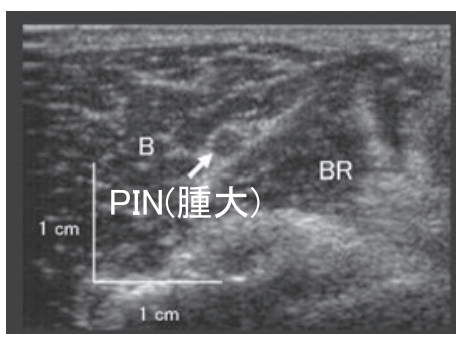

B

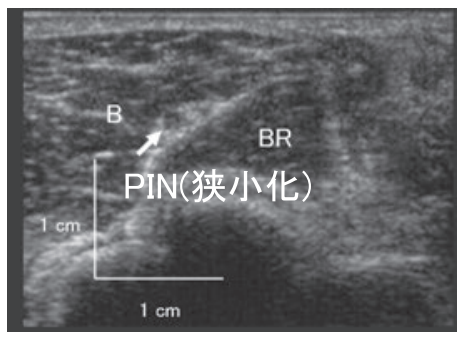

C

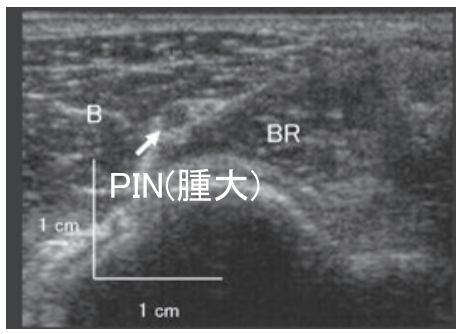

E

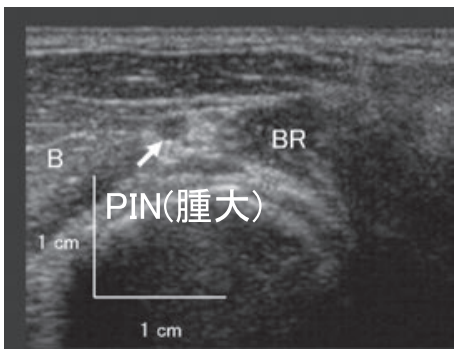

$\mathrm{F}$

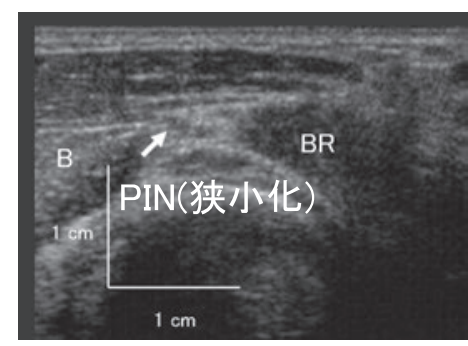

G

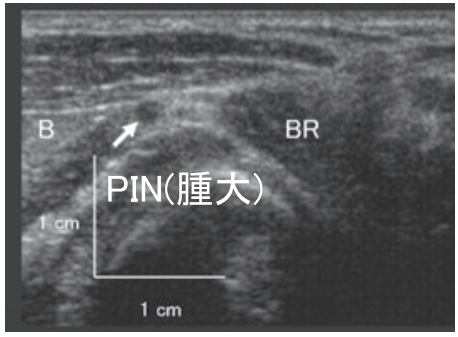

D

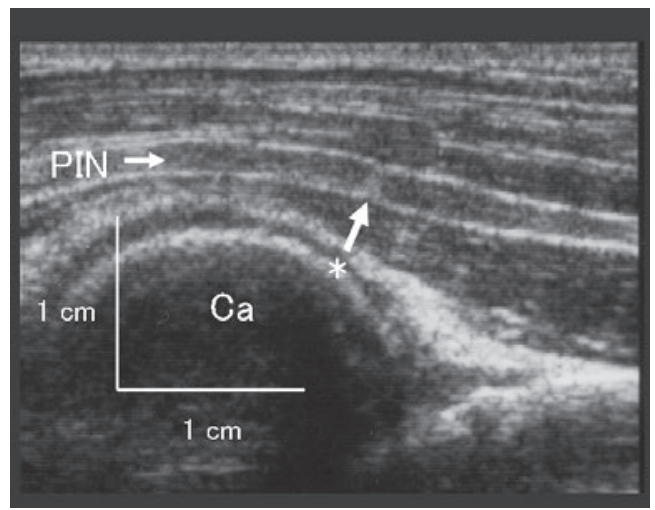

$\mathrm{H}$

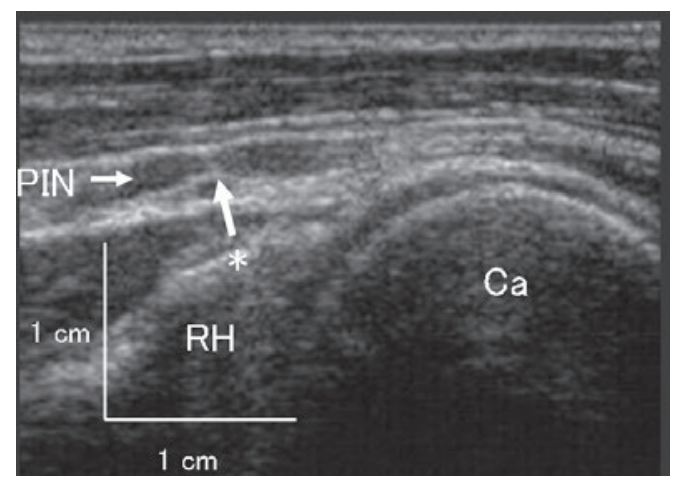

I

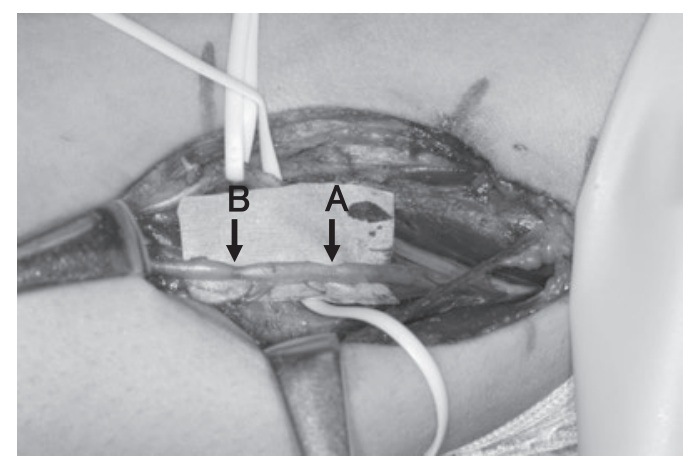

図 2 PIN のくびれ（表：症例 3）

$(\mathrm{A} \sim \mathrm{C})$ 上腕骨小頭高位の US 横断像 (左：内側, 上：前方). 上腕 筋（B）と腕橈骨筋（BR）の間に腫大した PIN を認めた（A)。遠位 に追跡すると，やや PIN 径の隇少を認める筒所があった（B)。より 遠位では, 再び PIN の腫大を認めた (C).（D）同部位の US 長軸像 (左：遠位, 上：前方). PIN に軽度のくびれがみられた。同部で内 部に帯状の高エコー域があり, PINの近, 遠位が境されていた $(*)$. $(\mathrm{E} \sim \mathrm{G})$ 橈骨頭高位の US 横断像 (左：内側, 上: 前方). 上腕筋 $(B)$ と腕橈骨筋（BR）の間に腫大したPINを認めた（E)。遠位に追跡 すると, PIN が認識しにくく，とぎれているように見える箇所が あった (F)。より遠位では, 再び PIN の腫大を認めた $(\mathrm{G})$. $(\mathrm{H})$ 同部位の US 長軸像（左：遠位，上：前方).（D）よりも高度なくび れを認めた $(*)$. (I) 術中写真 (左：遠位, 上：内側). A が上腕 骨小頭高位，B が橈骨頭高位のくびれに相当する。

$(\mathrm{Ca}$ ：上腕骨小頭, $\mathrm{RH} ：$ 橈骨頭) 

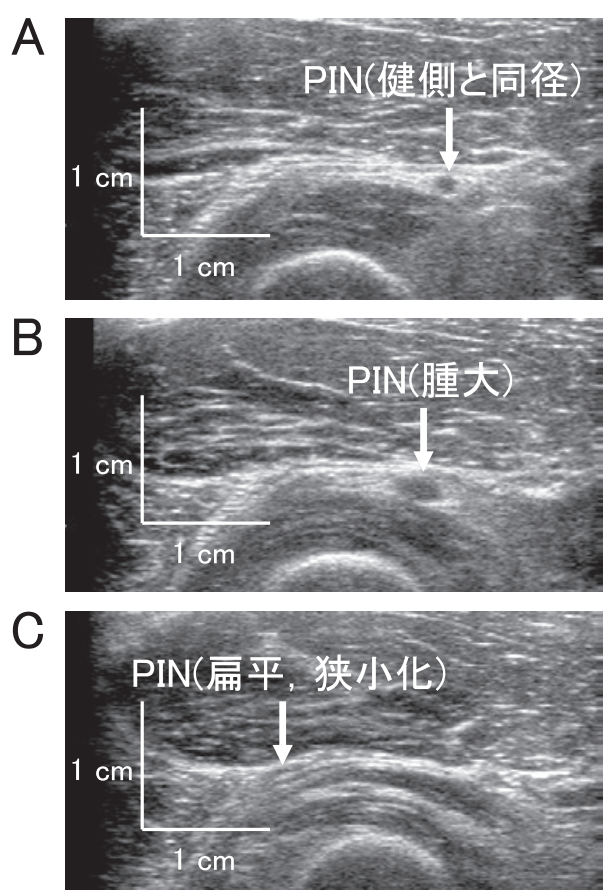

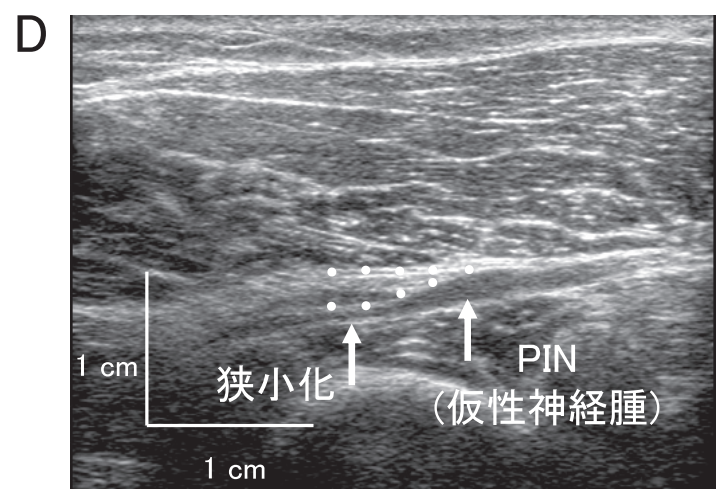

図 3 PIN の絞扼（回外筋症候群）（表：症例 6)

$(\mathrm{A} \sim \mathrm{C})$ US 横断像（左：外側，上：前方)．PINは，回外筋の近位（A）では腫大していなかったが，回外筋 入口部 (B) で腫大し, 回外筋に入った部位 (C) で, 扁平, 狭小化していた. (D) 同部の US 長軸像 (左: 遠位, 上：前方）. PIN は Frohse 腱弓（ドット）近位で腫大（仮性神経腫）し，腱弓下で狭小化していた。

1），痛みが軽度であるPIN のくびれ（症例 $3 ， 4) ，$ 誘 因のない回外筋症候群（症例 7）での診断は困難であ る。そのため従来，原因の確定は神経展開手術によら ざるを得なかった。これに対し，自験例ではこれを USにより非侵襲的に行い，治療法を立案できた。

従来報告と比較して，自験例ではPINをより詳細 に観察できた。占拠性病変では橈骨頚部前方に腫瘤を 証明する. US は囊腫性病変の描出に優れるため，ガ ングリオンでは特に有用とされる ${ }^{10)}$. 自験例（症例 1 , 2）でもその認識は容易で，くわえてPINの挙上と Frohse 腱弓による圧迫像も描出できたＰIN のくび れは，まず横断像の追跡で径の減少をとらえ，同部で 長軸像を得る方法 ${ }^{2)} に よ り$ 認識できた（症例 $3 ， 4$, 5).さらに, PIN は 3 例とも全長性に腫大しており, これにも診断的価值があると考える．回外筋症候群は 同筋近位部での PIN の腫大（仮性神経腫）により診

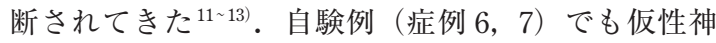
経腫を認め, さらに Frohse 腱弓下での圧迫像も描出 できこれらは絞扼性神経障害に特徴的な形態変化と 考えられた。
PIN のくびれと回外筋症候群はいずれも神経腫大と 狭小化像を呈するため, 両者の鑑別が問題となる. 従 来報告 ${ }^{2,11 \sim 13)}$ と自験例をあわせると, 腫大は, 回外 筋症候群では Frohse 腱弓近位の仮性神経腫のみ，く びれでは全長あるいはびまん性，狭小化の部位は，回 外筋症候群では絞扼部すなわち Frohse 腱弓部に一致 するのに対し，〈びれでは不定（外的圧迫のない部 位), 狭小化の数は回外筋症候群では 1 力所 (絞扼部), くびれは通常複数であることから鑑別可能と考える.

他の画像診断法としてはMRIがあるが，今回は 行っていないため, 自験例での US との比較はできな かった，一般的な見解として，占拠性軟部病変につい ては，囊腫性病変はUS，MRI のいずれでも診断可能 であり, 実質性病変は, MRIで信号強度により脂肪 腫など診断可能な病変があること, 造影により追加情 報があることが挙げられる。回外筋症候群について は, US, MRI とも横断像で回外筋入口部近位での神 経腫大（仮性神経腫）を証明できる ${ }^{12,13)}$. 神経の長軸 像の描出は，US が有用とされる。これは，USでは 走査面が神経長軸に沿うように探触子を細かく位置決 
めできるのに対し，MRIでは断層面の随時の変更が 困難なことによる ${ }^{12,13)}$ 。〈びれはUSで証明されてい るが，MRIによる報告はない，上記，および占拠性 病変はガングリオンの頻度が高いこと，さらに簡便性 とコストも考慮すると，本麻痺ではまずUSを用い， 実質性占拠性病変の精査等, 必要に応じ MRI を追加 することが実際的と考えられる。自験例での占拠性病 変はガングリオンであったため, US のみで診断でき た。

本研究の制約として, 症例数が少なく，ガングリオ ンを除く占拠性病変の画像の分析や感度，特異度など 診断能の検討, US 所見と臨床および電気生理学的検 査との関係の分析が課題であること, 全例で手術対比 を行っていないこと，単一検者であり，検者間誤差の 検討を要することが挙げられる.

末梢神経障害は主に臨床および電気生理学的に診断 が行われてきた。しかし，形態学的異常をともなう絞 扼性神経障害（手根管症候群，时部管症候群など), 占拠性病変などの局所病変，神経腫瘍では US の有用 性が認識されつつある ${ }^{14)}$. 自験例では非外傷性 PIN 麻痺の原因が同定でき，非侵襲性で簡便な US はこの 目的にも有用と考える.

\section{文献}

1）長野 昭, 屋宜 公, 杉岡 宏: 絞扼性神経障害の臨床 : 後骨間神経麻痺と前骨間神経麻麻痺. Monthly Book Orthopaedics $1990 ; 22: 31-37$

2) Nakamichi K, Tachibana S : Ultrasonographic findings in isolated neuritis of the posterior interosseous nerve : comparison with normal findings. J Ultrasound Med $2007 ; 26: 683-687$

3) Sakamoto A, Yoshida T, Mitsuyasu H, Iwamoto Y : Lipoma causing posterior interosseous nerve palsy or super- ficial radial nerve paraesthesia. J Hand Surg 2011 ; 36B : 76-77

4) Madhavan P, Leslie IJ : Intracapsular chondroma of the elbow producing a posterior interosseous nerve palsy. J Hand Surg 1998 ; 23B : 107-108

5) Busa R, Adani R, Marcuzzi A, Caroli A : Acute posterior interosseous nerve palsy caused by a synovial haemangioma of the elbow joint. J Hand Surg 1995 ; 20B : 652654

6) Sakai H, Fujioka H, Makino T : Posterior interosseous nerve palsy caused by a myxoma. J Hand Surg 2008 ; 33B : 84-85

7) Fujioka H, Futani H, Fukunaga S, Okuno H, Kano M, Tsukamoto Y, Tanaka J, Yoshiya S : Posterior interosseous nerve palsy caused by synovial chondromatosis arising in the annular periradial recesses of the elbow. Mod Rheumatol $2011 ; 21: 192-196$

8) Monacelli G, Ceci F, Prezzemoli G, Spagnoli A, Lotito S, Irace $\mathrm{S}$ : Posterior interosseous nerve palsy by synovial cyst of proximal radioulnar joint : our experience after 5 years. J Neurosurg Sci $2011 ; 55$ : 93-96

9) 田崎憲一, 堀内行雄, 矢部 裕: 末梢神経のくびれ. Monthly Book Orthopaedics 2002 ; 15 : 43-48

10) Ogino $T$, Minami $A$, Kato $H$ : Diagnosis of radial nerve palsy caused by ganglion with use of different imaging techniques. J Hand Surg $1991 ; \mathbf{1 6 A}: 230-235$

11) Bodner G, Harpf S, Meirer R, Gardetto A, Kovacs P, Gruber $\mathrm{H}$ : Ultrasonographic appearance of supinator syndrome. J Ultrasound Med 2002 ; 21 : 1289-1293

12) Chien AJ, Jamadar DA, Jacobson JA, Hayes CW, Louis DS : Sonography and MR imaging of posterior interosseous nerve syndrome with surgical correction. AJR $2003 ; 181: 219-221$

13) Kinni V, Craig J, van Holsbeeck Marnix, Ditmars D : Entrapment of the posterior interosseous nerve at the arcade of Frohse with sonographic, magnetic resonance imaging, and intraoperative confirmation. J Ultrasound Med $2009 ; 28: 807-812$

14）中道健一: 末梢神経障害に対する超音波診断. Monthly Book Orthopaedics $2012 ; 25: 11-22$ 